\title{
EVALUASI KESESUAIAN LAHAN UNTUK PENGEMBANGAN EKOWISATA PENDIDIKAN DI POLITEKNIK PEMBANGUNAN PERTANIAN GOWA
}

\section{Land Suitability Evaluation for Development of Educational Ecotourism on Gowa Agricultural Development Polytechnic}

\author{
Kaharuddin $^{1}$, M. Nathan ${ }^{2}$, Syaifuddin ${ }^{1}$, dan Hermaya Rukka ${ }^{1}$ \\ ${ }^{1}$ Politeknik Pembangunan Pertanian (Polbangtan) Gowa \\ ${ }^{2}$ Departemen Ilmu Tanah, Fakultas Pertanian, Universitas Hasanuddin, Makassar \\ e-mail: kaharsig70@gmail.com
}

Received: 24 Maret 2020; Accepted: 18 April 2020; Published: 30 Juni 2020

\begin{abstract}
ABSTRAK
Politeknik Pembangunan Pertanian (Polbantan) Gowa memiliki potensi untuk dijadikan sebagai lokasi ekowisata pendidikan, karena ditunjang oleh luas lahan yang dimiliki sekitar 58 ha dan aksesibilitas sangat baik, karena berada pada jalur utama Kota Makassar menuju Kota Malino yang merupakan salah satu destinasi wisata utama di Provinsi Sulawesi Selatan. Penelitian bertujuan untuk melakukan: 1) survei karakteristik lahan untuk kesesuaian pengembangan berbagai jenis ekowisata, 2) kajian evaluasi lahan untuk menguji tingkat kesesuaian lahan berbagai jenis ekowisata. Survei karakteristik lahan dilakukan secara detail dengan menggunakan sistim grid untuk memperoleh data biofisik lahan, sedangkan metode evaluasi lahan yang digunakan adalah metode evaluasi lahan untuk pariwisata. Hasil penelitian menunjukkan bahwa pada Unit Lahan 1 dan 2, sesuai untuk berbagai jenis penggunaan sarana ekowisata seperti tempat bermain, tempat berkemah, taman rekreasi, dan lokasi lintas alam, sedangkan pada Unit Lahan 3 tidak sesuai untuk penggunaan berbagai jenis sarana ekowisata, karena adanya faktor pembatas berupa potensi bahaya banjir dan drainase tanah yang sangat buruk, serta kedalaman air tanah yang dangkal.
\end{abstract}

Kata kunci: Evaluasi kesesuaian lahan, ekowisata pendidikan, Polbangtan Gowa.

\begin{abstract}
Gowa Agricultural Development Polytechnic (Polbangtan Gowa) has the potential to be used as an educational ecotourism location, because it is supported by an area of land owned at least 58 ha and excellent accessibility, because it is on the main route of Makassar City towards Malino City which is one of the main tourist destinations in the South Sulawesi Province. The research aims to conduct: 1) survey of land characteristics for the suitability of developing various types of ecotourism, 2) land evaluation studies to test the suitability of various types of ecotourism land. The land characteristics survey is carried out in detail by using a grid system to obtain land biophysical data, while the land evaluation method used is the land evaluation method for tourism. The results showed that Land Unit 1 and 2 were suitable for various types of ecotourism facilities such as playground, camping ground, recreational parks, and cross-country locations, whereas Land Unit 3 was not suitable for the use of various types of ecotourism facilities, due to factors barrier in the form of potential danger of flooding and very poor soil drainage, and shallow ground water depths.
\end{abstract}

Keywords: Land suitability evaluation, educational ecotourism, Polbangtan Gowa.

Diterbitkan Oleh,

Unit Penelitian dan Pengabdian Masyarakat, Politeknik Pembangunan Pertanian Gowa

http://ejournal.polbangtan-gowa.ac.id 


\section{PENDAHULUAN}

Lokasi Sekolah Tinggi Penyuluhan Pertanian (STPP) Gowa yang bertransformasi menjadi Politeknik Pembangunan Pertanian (Polbangtan) Gowa di Kecamatan Bontomarannu, Kabupaten Gowa, berada pada posisi yang strategis dari sisi aksesibilitas, karena terletak pada poros jalur utama Kota Makassar menuju Kota Malino yang merupakan salah satu lokasi wisata utama di Provinsi Sulawesi Selatan. Posisi strategis lokasi yang dimiliki, ditambah dengan areal kampus yang luasnya mencapai 58 ha, menjadikan kampus yang mendidik tenagatenaga terampil di bidang pertanian tersebut, memiliki potensi untuk dijadikan berbagai jenis destinasi ekowisata, khususnya ekowisata pendidikan untuk masyarakat di Kota Makassar dan sekitarnya, bahkan untuk masyarakat Sulawesi Selatan pada umumnya.

Dalam penentuan rencana penggunaan lahan suatu kawasan, sangat dibutuhkan adanya rekomendasi penggunaan lahan yang berdasar pada hasil evaluasi kesesuaian lahan. Hasil evaluasi kesesuaian lahan ini merupakan titik tolak dalam pengambilan keputusan untuk suatu peruntukan yang sesuai dengan kapabilitas lahan. penggunaan lahan yang sesuai dengan peruntukkannya akan membuat tanah lebih berkelanjutan (sustainability) dan terhindar dari terjadinya degradasi lahan. Pemanfaatan sumberdaya lahan yang tidak sesuai dengan peruntukannya akan berdampak terhadap menurunnya kemampuan lahan di suatu wilayah, dan hal tersebut merupakan suatu kesalahan dalam sistem tataguna lahan (Herwanto et. al, 2013). Moniaga (2011) menegaskan bahwa keberlanjutan daya dukung lahan tidak terlepas dari peran pemilik/pengelola lahan, dan adanya proses geomorfologi yang terjadi pada lahan tersebut, seperti erosi yang berdampak pada terjadinya degradasi lahan.

Untuk menghindari terjadinya degradasi lahan, maka dibutuhkan perencanaan penggunaan lahan yang sangat detail sebagai acuan dalam penentuan penggunaan lahan. Baja (2012a) mengungkapkan bahwa perencanaan penggunaan lahan sangat dibutuhkan untuk mengarahkan pengambil keputusan untuk menentukan jenis penggunaan lahan dan lokasi spasial yang optimal untuk kegiatan yang direncanakan, mengidentifikasi dan merumuskan peluang perubahan pemanfaatan lahan, dan mengantisipasi konsekuensi perubahan kebijakan penggunaan lahan. Lebih lanjut dijelaskan pula bahwa dengan evaluasi sumberdaya lahan, maka dapat ditentukan kemampuan, kesesuaian, dan ketersediaan lahan untuk alternatif penggunaan lahan. Baja (2012b) menguraikan bahwa penggunaan lahan adalah berkaitan dengan kegiatan manusia memanfaatkan sumberdaya lahan dan sumberdaya lainnya dan memberikan pengaruh terhadap lahan tersebut

Dalam konteks pemanfaatan lahan untuk pengembangan berbagai atraksi wisata (terutama yang terkait dengan pemanfaatan lahan), diperlukan sejumlah data dan informasi berupa peta tingkat kesesuaian setiap segmen atau unit lahan terhadap berbagai jenis lokasi atraksi wisata. Kesesuaian lahan adalah tingkat kecocokan satu tipe lahan tertentu untuk tujuan penggunaan tertentu, mungkin untuk saat ini ataupun setelah dilakukan perbaikan (FAO, 1979). Proses penentuan kesesuaian lahan dilakukan dengan melakukan penyelidikan atas areal spesifik tertentu terhadap tujuan penggunaan tertentu pula. Dalam hal ini yang dimaksud adalah berbagai jenis atraksi ekowisata (yang direncanakan). Ketidakberhasilan pembangunan/ pengembangan ekowisata di suatu wilayah sering diakibatkan oleh tidak lengkapnya data dan informasi agroekologi khususnya sumberdaya lahan. Oleh sebab itu diperlukan data dan informasi yang lengkap melalui evaluasi kesesuaian lahan. Adapun permasalahan yang akan dikaji adalah bagaimanakah potensi lahan Polbangtan Gowa, terkait dengan pengembangan ekowisata. Penelitian bertujuan untuk melakukan: 1) survei karakteristik lahan untuk kesesuaian pengembangan berbagai jenis ekowisata, 2) kajian evaluasi lahan untuk menguji tingkat kesesuaian lahan berbagai jenis ekowisata.

\section{METODE PENELITIAN}

\section{Survei dan Deliniasi Unit Lahan}

Tanah dalam satu unit lahan yang sama, diasumsikan memiliki kondisi biofisik yang seragam, dan karena itu memiliki potensi yang relatif sama. Suatu unit lahan dapat memiliki

Diterbitkan Oleh, 
kesamaan dalam hal faktor-faktor pembentuk tanah (iklim, lereng, vegetasi, bahan induk, dan waktu pembentukan tanah) dan menyebabkan adanya kesamaan dalam hal potensi sumberdaya lahan. Deliniasi unit lahan dilakukan dengan faktor pertimbangan utamanya adalah homogenitas dalam hal kondisi biofisik-kimia dari tanah di lokasi tersebut. Mengingat lokasi Polbangtan Gowa, relatif memiliki kesamaan dalam hal kondisi geologi, lereng, vegetasi dan jenis tanah pada tingkat ordo, maka dasar yang digunakan dalam deliniasi unit lahan (satuan peta tanah, SPT) adalah hasil survei detail yang dilakukan dengan metode survei Grid System. Titik-titik pengamatan tanah dengan metode Grid
System yang dilakukan dapat dilihat pada Gambar 1.

\section{Data Biofisik Untuk Evaluasi Kesesuaian Lahan}

Data biofisik yang dibutuhkan untuk penentuan jenis sarana rekreasi ekowisata yang sesuai pada unit lahan tertentu adalah: Kondisi drainase tanah, bahaya banjir, permeabilitas, lereng, tekstur tanah permukaan, kedalaman sampai hamparan batuan, keberadaan kerikil dan kerakal $(0,2 \mathrm{~cm}-25 \mathrm{~cm})$, keberadaan batu $(25 \mathrm{~cm}-$ $60 \mathrm{~cm}$ ) dan keberadaan batuan (bedrock) di atas $60 \mathrm{~cm}$.

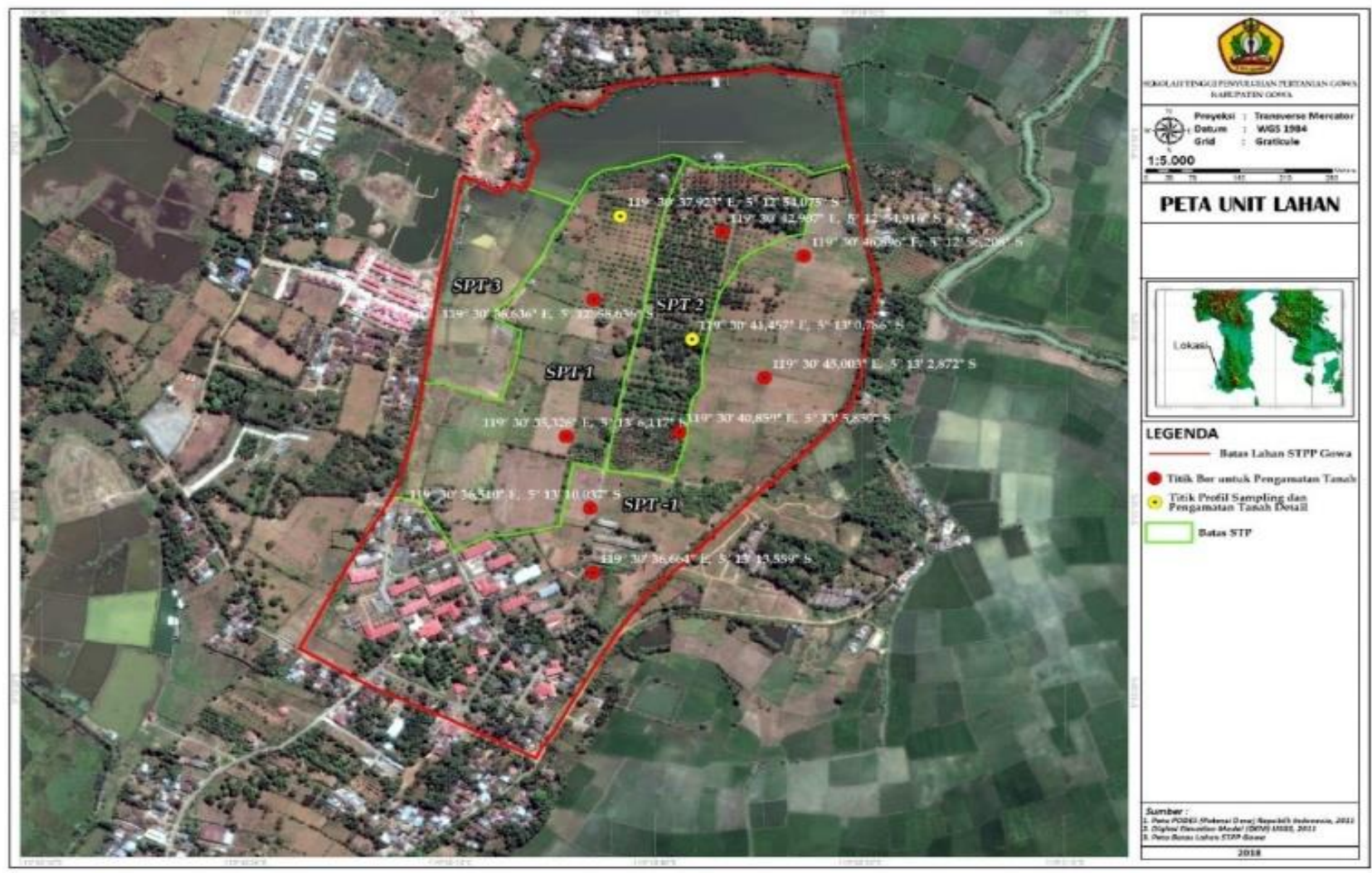

Gambar 1. Peta Unit Lahan Polbangtan Gowa

\section{Metode Evaluasi Lahan}

Metode evaluasi lahan yang dipergunakan adalah metode Evaluasi Lahan Untuk Pariwisata (Hardjowigeno et. al, 1994; Hardjowigeno dan Widiatmaka, 2011). Setiap unit lahan yang ada, dievaluasi kesesuaiannya

Diterbitkan Oleh,

Unit Penelitian dan Pengabdian Masyarakat, Politeknik Pembangunan Pertanian Gowa http://ejournal.polbangtan-gowa.ac.id untuk pengembangan berbagai jenis sarana ekowisata, sesuai metode evaluasi yang telah disebutkan. Tingkat kesesuain lahan setiap jenis ekowisata tersebut dikelompokkan dalam "Baik", "Sedang" dan "Buruk". Adapun berbagai jenis sarana rekreasi ekowisata yang dievaluasi adalah: Lapangan tempat bermain (playground), tempat 
berkemah (camping ground), Taman Rekreasi dan Lintas Alam.

\section{HASIL DAN PEMBAHASAN}

\section{Hasil}

\section{Iklim}

Lokasi Polbangtan Gowa berada pada zona dengan curah hujan rata-rata tahunan $2.441 \mathrm{~mm}$ per tahun. Curah hujan tahunan sebesar $2.441 \mathrm{~mm}$ per tahun tersebut terdistribusi setiap bulan. Intensitas curah hujan tertinggi terjadi pada bulan Januari dan Desember dengan curah hujan sebesar $537 \mathrm{~mm}$ dan 437 mm (sumber: Global Weather, 2017).

Suhu udara rata-rata di Polbangtan Gowa antara $21,77^{\circ} \mathrm{C}$ (rata-rata terendah) hingga $34,07^{\circ} \mathrm{C}$ (rata-rata tertinggi). Suhu udara minimum terendah jatuh pada Bulan Agustus, sedangkan suhu udara maksimum tertinggi jatuh pada Bulan Oktober (sumber: Global Weather, 2017). Kelembaban udara rata-rata nisbi bulanan di Polbangtan Gowa mencapai titik tertinggi pada bulan Februari dengan kelembaban udara 83,61\%, sedangkan kelembaban udara terendah sepanjang tahun dicapai pada bulan September, dengan kelembaban udara nisbih 64,60 $\%$ (sumber: Global Weather, 2017).

\section{Geologi dan Geomorfologi}

Lokasi Polbangtan Gowa merupakan daerah bergelombang, cenderung datar dengan kemiringan lereng $<8 \%$. Karena itu, satuan morfologi daerah ini dikatagorikan sebagai satuan geomorfologi dataran rendah dengan ketinggian (elevasi) kurang dari $25 \mathrm{~m} \mathrm{dpl}$.

Stratigrafi Polbangtan Gowa berdasarkan Peta Geologi Lembar Ujung Pandang (Sukamto, dan Supriatna, 1982) disusun oleh Formasi (dari muda ke tua): a) Formasi Qac (Formasi Quarter Alluvium Coastal); formasi ini terdiri dari kerikil, pasir, lempung, lumpur dan batugamping koral yang terbentuk dalam lingkungan sungai, pantai dan delta. Qac yang terdapat di Kabupaten Gowa endapan aluviumnya terutama terdiri dari rombakan batuan gunungapi Lompobattang. b) Formasi Tpbv (Formasi Batuan Gunung Api Baturappe-Cindakko); formasi ini terdiri dari lava, breksi, tuva dan konglomerat.

\section{Topografi}

Lokasi Polbangtan Gowa memiliki topografi datar hingga bergelombang dengan kemiringan lereng $<3 \%$. Kemiringan lereng yang mengarah dari Selatan (Lokasi Bangunan Kampus) ke Utara dimana Danau Polbangtan Gowa berlokasi (Gambar 1), memiliki keuntungan dari sisi drainase dan ketersediaan air, karena lokasi kampus akan relatif aman dari genangan air di musim hujan, sementara Danau Polbangtan Gowa yang merupakan reservoar penampung air hujan akan menampung air larian (run off) yang dapat digunakan untuk keperluan irigasi di musim kemarau.

Jika dikaitkan dengan pemanfaatan lahan untuk wisata, topografi datar-bergelombang yang dimiliki lahan Polbangtan Gowa, tergolong topografi yang sangat ideal. Hampir semua jenis wisata dapat direkomendasikan pengembangannya pada topografi yang relatif datar karena relatif aman dari bahaya longsor. Berbeda dengan lahan dengan topografi yang terjal, misalnya, tidak direkomendasikan untuk wisata, karena alasan mudahnya lahan tersebut tererosi bahkan terjadi longsor pada musim hujan.

\section{Tanah}

Hasil pengamatan yang intensif pada 10 titik pemboran, termasuk 2 (dua) titik Profil di lokasi Polbangtan Gowa (Gambar 2) menghasilkan data dan informasi sebagai berikut:

\section{a. Jenis Tanah}

Tanah di lokasi Polbangtan Gowa berdasarkan Kunci Taksonomi Tanah (Soil Suvey Staff, 2014) didominasi oleh tanah dari Ordo Alfisols pada Unit Lahan 1 dan Unit Lahan 2 (Subordo Ustalfs, Great Group Rhodostalfs). Pada bagian landform yang lain, yakni pada bagian Barat dari Lahan Polbangtan Gowa dijumpai tanah dari Ordo Inceptisol (Sub-ordo Aquepts, Great Group Endoaquepts), yang tersebar di sekitar lokasi Danau Polbangtan Gowa, dengan penggunaan lahan sebagai sawah. Sebaran dari kedua jenis tanah utama yang dijumpai di lokasi penelitian, dapat dilihat pada Gambar 2. 


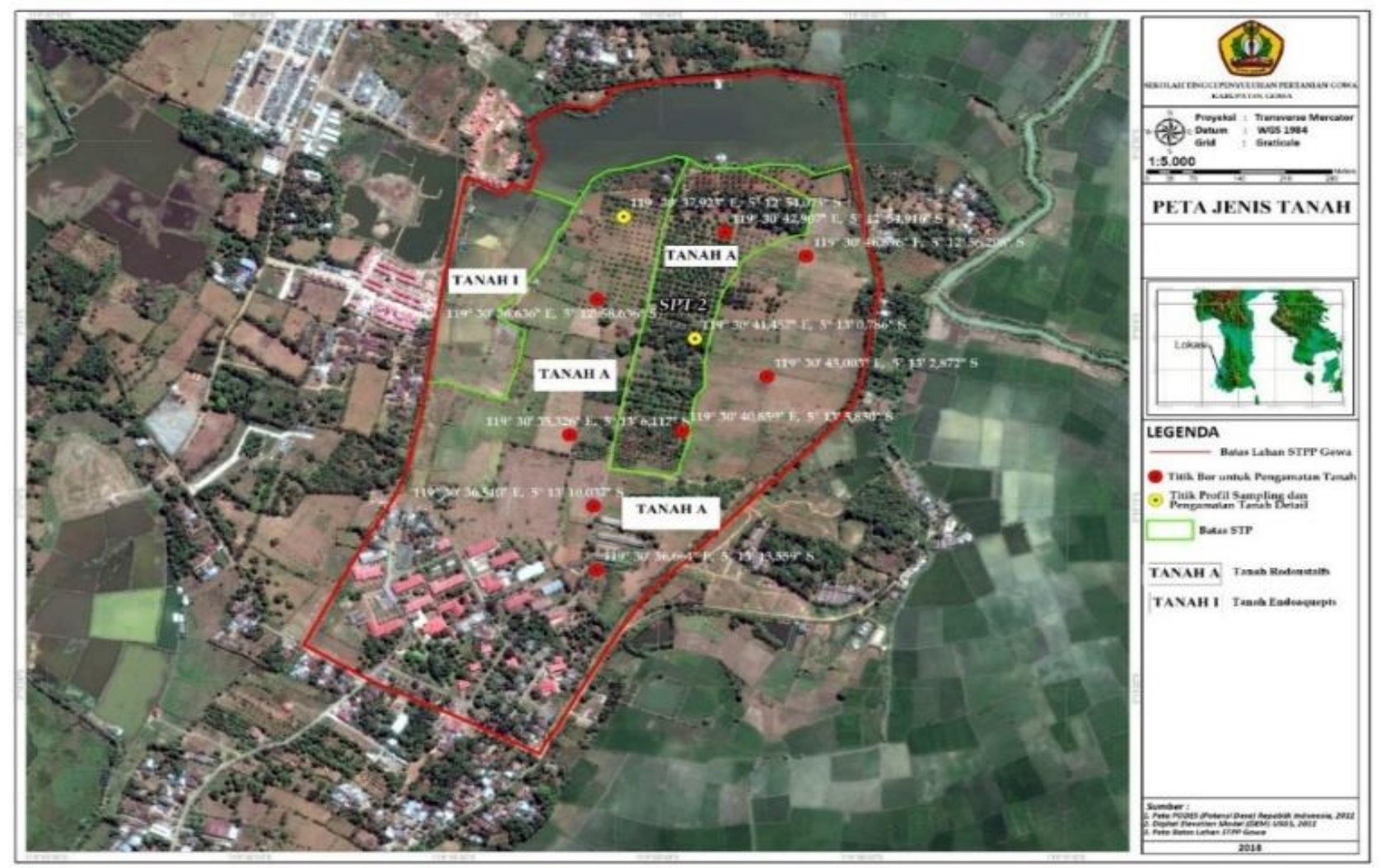

Gambar 2. Peta Jenis Tanah Polbangtan Gowa

\section{b. Deskripsi Profil Tanah}

Sifat tanah di Polbangtan Gowa, secara umum tergambar pada Tabel 1. Tanah di Polbangtan Gowa umumnya tergolong tanah dalam, bertekstur halus dan berdrainase baik. Meskipun demikian, juga dijumpai tanah dengan drainase jelek, yang tergenang pada musim hujan, dan digunakan sebagai lahan sawah.

\section{c. Sifat Fisik Tanah}

Hasil pengamatan sifat fisik tanah di lapangan menunjukkan bahwa, pada Unit Lahan 1 dan 2 memiliki drainase yang cepat dan permeabilitas berkisar dari cepat sampai sangat cepat, sehingga terbebas dari bahaya banjir, sedangkan pada Unit Lahan 3 mempunyai drainase lambat sampai sangat lambat dan tergenang pada musim hujan. Adapun hasil analisis tekstur tanah Unit Lahan 1 dan 2 dapat dilihat pada Tabel 2, menunjukkan bahwa tekstur tanah didominasi oleh tekstur liat, meskipun pada Profil 2, lapisan permukaannya memiliki tekstur yang relatif lebih kasar yakni lempung liat berdebu.

\section{d. Kerikil, Kerakal, Batu, dan Batuan}

Hasil pengamatan menunjukkan bahwa keberadaan kerikil, kerakal, dan batu sangat minim $(<0,01 \%)$. Adapun keberadaan batuan (bedrock) tidak ada sama sekali (0 \%) untuk semua unit lahan.

\section{PEMBAHASAN}

\section{Kesesuaian Lahan Untuk Tempat Bermain}

Hasil penilaian kondisi biofisik lahan Polbangtan Gowa berdasarkan kriteria kesesuaian lahan untuk tempat bermain pada Tabel 3, maka dapat diuraikan bahwa Unit Lahan 1 dan 2 tergolong "baik" untuk dipilih sebagai lokasi tempat bermain, sedang Unit Lahan 3 tergolong bukan tempat yang baik atau klasifikasi "buruk" untuk tempat bermain, karena faktor penghambat berupa potensi bahaya banjir dan drainase tanah yang sangat buruk, serta kedalaman permukaan air tanah yang dangkal.

Diterbitkan Oleh,

Unit Penelitian dan Pengabdian Masyarakat, Politeknik Pembangunan Pertanian Gowa

http://ejournal.polbangtan-gowa.ac.id 
Tabel 1. Deskripsi Profil Tanah di Polbangtan Gowa

\begin{tabular}{|c|c|c|c|}
\hline \multirow{2}{*}{$\begin{array}{r}\text { Kode Profil } 1 \\
\text { (Unit Lahan 1) }\end{array}$} & \multicolumn{3}{|c|}{$\begin{array}{l}\text { Deskripsi umum; lereng }<2 \% \text {, kebun dengan vegetasi utama tanaman mangga, semak } \\
\text { belukar dan tanaman perdu lainnya, elevasi } 18 \mathrm{~m} \text { dpl, drainase baik. }\end{array}$} \\
\hline & Kedalaman (cm) & Horizon & Karakteristik \\
\hline & $0-27$ & $\mathrm{~A}$ & $\begin{array}{l}\text { Coklat kuning gelap (10YR 4/4); liat; struktur gumpal } \\
\text { bersudut; sedang sedang; gembur lekat dan agak plastis; pori } \\
\text { halus banyak; pori sedang dan kasar sedikit; akar halus } \\
\text { banyak, agak masam }\end{array}$ \\
\hline & $28-56$ & Bt1 & $\begin{array}{l}\text { Coklat kekuningan gelap (10YR 4/4); liat; struktur gumpal } \\
\text { bersudut; sedang sedang; gembur lekat dan agak plastis; pori } \\
\text { halus banyak; pori sedang dan kasar sedikit; akar halus } \\
\text { banyak, agak masam }\end{array}$ \\
\hline & $57-150$ & Bt2 & $\begin{array}{l}\text { Coklat kekuningan gelap (10YR 4/6); liat; struktur gumpal } \\
\text { bersudut; sedang sedang; gembur lekat dan agak plastis; pori } \\
\text { halus banyak; pori sedang dan kasar sedikit; akar halus } \\
\text { banyak, agak masam }\end{array}$ \\
\hline \multirow{5}{*}{$\begin{array}{r}\text { Kode Profil } 2 \\
\text { (Unit Lahan 2) }\end{array}$} & \multicolumn{3}{|c|}{$\begin{array}{l}\text { Deskripsi umum; lereng }<2 \% \text {, kebun dengan vegetasi utama tanaman rambutan, semak } \\
\text { belukar dan tanaman perdu lainnya, elevasi } 12 \mathrm{~m} \mathrm{dpl} \text {, drainase baik }\end{array}$} \\
\hline & $\begin{array}{l}\text { Kedalaman } \\
\quad(\mathrm{cm})\end{array}$ & Horizon & Karakteristik \\
\hline & $0-20$ & A & $\begin{array}{l}\text { Coklat tua (7,5YR4/6); lempung liat berdebu: struktur } \\
\text { gumpal membulat; gembur agak lekat dan tidak plastis; pori } \\
\text { halus dan sedang banyak; pori kasar cukup; akar sedang dan } \\
\text { kasar banyak; agak masam. }\end{array}$ \\
\hline & $21-48$ & Bt1 & $\begin{array}{l}\text { Coklat tua }(7,5 \text { YR } 4 / 6) \text {; liat berdebu: struktur gumpal } \\
\text { membulat; gembur agak lekat dan tidak plastis; pori halus dan } \\
\text { sedang banyak; pori kasar cukup; akar sedang dan kasar } \\
\text { banyak; agak masam. }\end{array}$ \\
\hline & $49-150$ & $\mathrm{Bt} 2$ & $\begin{array}{l}\text { Coklat tua }(7,5 \text { YR4/6); liat berdebu: struktur gumpal } \\
\text { membulat; gembur agak lekat dan tidak plastis; pori halus dan } \\
\text { sedang banyak; pori sedikit; akar sedang dan kasar sedikit; } \\
\text { agak masam. }\end{array}$ \\
\hline
\end{tabular}

Tabel 2. Hasil analisis tekstur tanah Profil-1 dan Profil 2 lahan Polbangtan Gowa

\begin{tabular}{cccccc}
\hline Kode & Kedalaman $(\mathrm{cm})$ & $\begin{array}{c}\text { Pasir } \\
(\%)\end{array}$ & $\begin{array}{c}\text { Debu } \\
(\%)\end{array}$ & $\begin{array}{c}\text { Liat } \\
(\%)\end{array}$ & Kelas Tekstur \\
\hline Profil 1 & $0-27$ & 13 & 24 & 63 & Liat \\
(Unit Lahan 1) & $28-56$ & 10 & 10 & 79 & Liat \\
& $57-150$ & 8 & 11 & 82 & Liat \\
\hline Profil 2 & $0-20$ & 12 & 54 & 34 & Lempung Liat Berdebu \\
(Unit Lahan 2) & $21-48$ & 7 & 36 & 58 & Liat \\
& $49-150$ & 10 & 25 & 64 & Liat \\
\hline
\end{tabular}

Diterbitkan Oleh, 
Tabel 3. Kesesuaian lahan untuk tempat bermain

\begin{tabular}{|c|c|c|c|}
\hline \multirow{2}{*}{ Sifat Tanah } & \multicolumn{3}{|c|}{ Kelas Kesesuaian dan Faktor Penghambat } \\
\hline & Baik & Sedang & Buruk \\
\hline Drainase Tanah & $\begin{array}{l}\text { Cepat, agak cepat, baik } \\
\text { dan agak baik. Air tanah } \\
\text { lebih dari } 75 \mathrm{~cm}\end{array}$ & $\begin{array}{l}\text { Agak baik dan agak } \\
\text { buruk. Air tanah lebih dari } \\
50 \mathrm{~cm}\end{array}$ & $\begin{array}{l}\text { Agak buruk, buruk, sangat } \\
\text { buruk. Air tanah kurang dari } \\
50 \mathrm{~cm}\end{array}$ \\
\hline Bahaya Banjir & Tidak pernah & Sekali dalam setahun & Lebih satu kali dalam setahun \\
\hline Permeabilitas & $\begin{array}{l}\text { Sangat cepat, cepat, } \\
\text { sedang }\end{array}$ & Agak lambat, lambat & Sangat Lambat \\
\hline Lereng & $0-2 \%$ & $2-6 \%$ & $>6 \%$ \\
\hline Tekstur tanah permukaan & sl, fsl, vfsl, l, sil & $\mathrm{cl}, \mathrm{scl}, \mathrm{sicl}, \mathrm{ls}$ & sc, sic, c, s, tanah organik \\
\hline $\begin{array}{l}\text { Kedalaman sampai } \\
\text { hamparan batuan }\end{array}$ & Lebih dari $100 \mathrm{~cm}$ & $50-100 \mathrm{~cm}$ & Kurang dari $50 \mathrm{~cm}$ \\
\hline $\begin{array}{l}\text { Kerikil dan kerakal }(0,2 \\
\mathrm{cm}-25 \mathrm{~cm})\end{array}$ & $0 \%$ & Kurang dari $20 \%$ & $>20 \%$ \\
\hline Batu $(25 \mathrm{~cm}-60 \mathrm{~cm})$ & $0 \%$ & $0,01-3 \%$ & $>3 \%$ \\
\hline Batuan $(>60 \mathrm{~cm})$ & $0 \%$ & $0,01-0,1 \%$ & $>0,1 \%$ \\
\hline
\end{tabular}

\section{Kesesuaian Lahan Untuk Tempat Berkemah}

Hasil penilaian kondisi biofisik lahan Polbangtan Gowa berdasarkan kriteria kesesuaian lahan untuk tempat berkemah pada Tabel 4, maka dapat diuraikan bahwa Unit Lahan 1 dan 2 tergolong "baik" untuk dipilih sebagai lokasi tempat berkemah, sedang Unit Lahan 3 tergolong bukan tempat yang baik atau klasifikasi "buruk" untuk tempat berkemah, karena faktor penghambat berupa potensi bahaya banjir dan drainase tanah yang sangat buruk, serta kedalaman permukaan air tanah yang dangkal.

Tabel 4. Kesesuaian lahan untuk tempat berkemah

\begin{tabular}{|c|c|c|c|}
\hline \multirow{2}{*}{ Sifat Tanah } & \multicolumn{3}{|c|}{ Kelas Kesesuaian dan Faktor Penghambat } \\
\hline & Baik & Sedang & Buruk \\
\hline Drainase Tanah & $\begin{array}{l}\text { Cepat, agak cepat, baik dan } \\
\text { agak baik. Air tanah lebih } \\
\text { dari } 75 \mathrm{~cm}\end{array}$ & $\begin{array}{l}\text { Agak baik dan agak buruk. } \\
\text { Aair tanah lebih dari } 50 \mathrm{~cm}\end{array}$ & $\begin{array}{l}\text { Agak buruk, buruk, sangat } \\
\text { buruk. Air tanah kurang } \\
\text { dari } 50 \mathrm{~cm}\end{array}$ \\
\hline Bahaya Banjir & Tidak pernah & Sekali dalam setahun & $\begin{array}{l}\text { Lebih satu kali dalam } \\
\text { setahun }\end{array}$ \\
\hline Permeabilitas & Sangat cepat, cepat, sedang & Agak lambat, lambat & Sangat Lambat \\
\hline Lereng & $0-8 \%$ & $8-15 \%$ & $>15 \%$ \\
\hline $\begin{array}{l}\text { Tekstur tanah } \\
\text { permukaan }\end{array}$ & sl, fsl, vfsl, l, sil & $\begin{array}{l}\text { cl, scl, sicl, ls, s (bukan } \\
\text { pasir lepas) }\end{array}$ & $\begin{array}{l}\text { sc, sic, pasir lepas (mudah } \\
\text { terbawa angin), tanah } \\
\text { organik }\end{array}$ \\
\hline $\begin{array}{l}\text { Kerikil dan kerakal }(0,2 \\
\mathrm{cm}-25 \mathrm{~cm})\end{array}$ & $0-20 \%$ & $20-50 \%$ & $>50 \%$ \\
\hline Batu $(25 \mathrm{~cm}-60 \mathrm{~cm})$ & $0-0,1 \%$ & $0,1-3 \%$ & $>3 \%$ \\
\hline Batuan $(>60 \mathrm{~cm})$ & $0-0,01 \%$ & $0,01-0,1 \%$ & $>0,1 \%$ \\
\hline
\end{tabular}

Diterbitkan Oleh,

Unit Penelitian dan Pengabdian Masyarakat, Politeknik Pembangunan Pertanian Gowa

http://ejournal.polbangtan-gowa.ac.id 


\section{Kesesuaian Lahan Untuk Taman Rekreasi}

Hasil penilaian kondisi biofisik lahan Polbangtan Gowa berdasarkan kriteria kesesuaian lahan untuk taman rekreasi pada Tabel 5, maka dapat diuraikan bahwa Unit Lahan 1 dan 2 tergolong "baik" untuk dipilih sebagai lokasi taman rekreasi, sedang Unit Lahan 3 tergolong bukan tempat yang baik atau klasifikasi "buruk" untuk taman rekreasi, karena faktor penghambat berupa potensi bahaya banjir dan drainase tanah yang sangat buruk, serta kedalaman permukaan air tanah yang dangkal.

Tabel 5. Kesesuaian lahan untuk taman rekreasi

\section{Kesesuaian Lahan Untuk Lokasi Lintas Alam}

Hasil penilaian kondisi biofisik lahan Polbangtan Gowa berdasarkan kriteria kesesuaian lahan untuk lokasi lintas alam pada Tabel 6, maka dapat diuraikan bahwa Unit Lahan 1 dan 2 tergolong baik untuk dipilih sebagai lokasi lintas alam, sedang Unit Lahan 3 tergolong bukan tempat yang baik atau klasifikasi "buruk" untuk lokasi lintas alam, karena faktor penghambat berupa potensi bahaya banjir dan drainase tanah yang sangat buruk, serta kedalaman permukaan air tanah yang dangkal.

\begin{tabular}{|c|c|c|c|}
\hline \multirow{2}{*}{ Sifat Tanah } & \multicolumn{3}{|c|}{ Kelas Kesesuaian dan Faktor Penghambat } \\
\hline & Baik & Sedang & Buruk \\
\hline Drainase Tanah & $\begin{array}{l}\text { Cepat, agak cepat baik } \\
\text { dan agak baik. Air } \\
\text { tanah lebih dari } 50 \mathrm{~cm}\end{array}$ & $\begin{array}{l}\text { Agak baik dan agak buruk. } \\
\text { Aair tanah lkurang dari } 50 \\
\mathrm{~cm}\end{array}$ & $\begin{array}{l}\text { Agak buruk, buruk, sangat } \\
\text { buruk. Air tanah kurang dari } 50 \\
\text { cm dan sering dekat permukaan }\end{array}$ \\
\hline Bahaya Banjir & Tidak pernah & Sekali dalam setahun & Lebih satu kali dalam setahun \\
\hline Lereng & $0-8 \%$ & $8-15 \%$ & $>15 \%$ \\
\hline Tekstur tanah permukaan & sl, fsl, vfsl, c, sil & $\mathrm{cl}$, scl, sicl, ls, s (tidak lepas) & $\begin{array}{l}\text { sc, sic, c, s (lepas), tanah } \\
\text { organik }\end{array}$ \\
\hline $\begin{array}{l}\text { Kedalaman sampai } \\
\text { hamparan batuan }\end{array}$ & Lebih dari $100 \mathrm{~cm}$ & $50-100 \mathrm{~cm}$ & Kurang dari $50 \mathrm{~cm}$ \\
\hline $\begin{array}{l}\text { Kerikil dan kerakal }(0,2 \\
\mathrm{cm}-25 \mathrm{~cm})\end{array}$ & $0-20 \%$ & $20-50 \%$ & $>50 \%$ \\
\hline Batu $(25 \mathrm{~cm}-60 \mathrm{~cm})$ & $0-3 \%$ & $3-15 \%$ & $>15 \%$ \\
\hline Batuan $(>60 \mathrm{~cm})$ & $0-0,1 \%$ & $0,1-3 \%$ & $>3 \%$ \\
\hline
\end{tabular}

Tabel 6. Kesesuaian lahan untuk lokasi lintas alam

\begin{tabular}{|c|c|c|c|}
\hline \multirow{2}{*}{ Sifat Tanah } & \multicolumn{3}{|c|}{ Kelas Kesesuaian dan Faktor Penghambat } \\
\hline & Baik & Sedang & Buruk \\
\hline Drainase Tanah & $\begin{array}{l}\text { Cepat, agak cepat baik } \\
\text { dan agak baik. Air } \\
\text { tanah lebih dari } 50 \mathrm{~cm}\end{array}$ & $\begin{array}{l}\text { Agak baik dan agak } \\
\text { buruk. Aair tanah } \\
\text { lkurang dari } 50 \mathrm{~cm}\end{array}$ & $\begin{array}{l}\text { Agak buruk, buruk, sangat } \\
\text { buruk. Air tanah kurang dari } \\
50 \mathrm{~cm} \text { dan sering dekat } \\
\text { permukaan }\end{array}$ \\
\hline Bahaya Banjir & Tidak pernah & Sekali dalam setahun & Lebih satu kali dalam setahun \\
\hline Lereng & $0-15 \%$ & $15-25 \%$ & $>25 \%$ \\
\hline Tekstur tanah permukaan & sl, fsl, vfsl, l, sil & cl, scl, sicl, ls & $\begin{array}{l}\text { sc, sic, c, s (lepas), tanah } \\
\text { organik }\end{array}$ \\
\hline $\begin{array}{l}\text { Kerikil dan kerakal }(0,2 \mathrm{~cm} \\
-25 \mathrm{~cm})\end{array}$ & $0-20 \%$ & $20-50 \%$ & $>50 \%$ \\
\hline Batu atau Batuan $(>25 \mathrm{~cm})$ & $0-0,1 \%$ & $0,1-3 \%$ & $>3 \%$ \\
\hline
\end{tabular}

Diterbitkan Oleh,

Unit Penelitian dan Pengabdian Masyarakat, Politeknik Pembangunan Pertanian Gowa http://ejournal.polbangtan-gowa.ac.id 


\section{KESIMPULAN}

Lokasi Polbangtan Gowa pada Unit Lahan 1 dan 2 sesuai digunakan untuk berbagai jenis sarana ekowisata seperti tempat bermain, tempat berkemah, taman rekreasi, dan lokasi lintas alam. Sedangkan pada Unit Lahan 3 tergolong tidak sesuai atau katagori "buruk", digunakan untuk berbagai jenis sarana ekowisata, karena adanya faktor pembatas berupa potensi banjir dan drainase tanah yang sangat buruk, serta kedalaman air tanah yang dangkal.

\section{DAFTAR PUSTAKA}

Baja, S., 2012a. Perencanaan Tata Guna Lahan dalam Pengembangan Wilayah, Pendekatan Spasial dan Aplikasinya. Penerbit Andi, Yogyakarta.

Baja, S., 2012b. Metode Analitik Evaluasi Sumber Daya Lahan, Aplikasi GIS, Fuzzy Set, dan MCDM. Identitas Universitas Hasanuddin, Makassar.

FAO, 1979. Land Suitability Classification. FAO Corporate Document Repository. http://www.fao.org/docrep/x5310e/x5310e 04.htm. Diakses 23 Maret 2017.

Global Weather, 2017. Data klimatologi lokasi penelitian.https://globalweather.tamu.edu/. Diakses 20 Oktober 2017.
Hardjowigeno S., Marsudi DS., H. Subagyo, N. Suharta, D. Djaenuddin, J. Dai., Basuni, Widagdo, V. Suwandi, L. Hakim, S. Buchari, E.R. Jordens, 1994. Evaluasi Lahan Untuk Pariwisata (Land Evaluation for Tourist Development). Second Land Resources Evaluation and Planning Project, ADB Loan No. 1099 INO, Part C. Strenghtening Soil Resources Mapping.

Hardjowigeno S. dan Widiatmaka, 2011. Evaluasi Kesesuaian Lahan dan Perencanaan Tataguna Lahan. Gadjah Mada University Press, Yogyakarta.

Herwanto, J.E., A. Sudarsono, B.S. Hadi, 2013. Pemanfaatan sistem informasi geografis untuk evaluasi kemampuan lahan di Kecamatan Samigaluh Kabupaten Kulonprogo. Geomedia 11(1): 42-51

Moniaga, V.R.B, 2011. Analisis daya dukung lahan pertanian. ASE 7(2): 61-68.

Sukamto dan Supriatna, 1982. Geologi lembar Ujung Pandang, Benteng, dan Sinjai, Sulawesi Selatan. Pusat Penelitian dan Pengembangan Geologi, Bandung.

Soil Suvey Staff, 2014. Keys to Soil Taxonomy, Twelfth Edition. United States Department of Agriculture, Washington DC. 